\title{
Symptomatic aggravation after corticosteroid pulse therapy in definite sporadic Creutzfeldt- Jakob disease with the feature of Hashimoto's encephalopathy
}

\author{
Jae-Won Jang ${ }^{1}$, So Young Park ${ }^{2,3}$, Young Ho Park ${ }^{2,3}$, Jung E Kim²,3 and SangYun Kim²,3*
}

\begin{abstract}
Background: Creutzfeldt-Jakob disease and Hashimoto's encephalopathy often show similar clinical presentation. Among Creutzfeldt-Jakob disease mimics, Hashimoto's encephalopathy is particularly important as it is treatable with corticosteroids. Thus, in cases of middle-aged woman diagnosed with probable Creutzfeldt-Jakob disease and who exhibit high titers of antithyroid antibodies, corticosteroid pulse therapy is typically performed with expectations of near complete recovery from Hashimoto's encephalopathy. Herein, we provide the first case report that exhibited a negative effect of corticosteroid pulse therapy for a patient with Creutzfeldt-Jakob disease with features of Hashimoto's encephalopathy.
\end{abstract}

Case presentation: We report a case of 59-year-old Asian woman with blurred vision, dysarthria, myoclonus, and rapidly progressive dementia. Cerebrospinal fluid showed 14-3-3 protein positive. Electroencephalogram showed periodic sharp waves $(1.5 \mathrm{~Hz})$ at the bilateral frontal or occipital areas. Magnetic resonance imaging showed high signal intensities at the bilateral cerebral cortex, caudate nucleus, and putamen. The patient was diagnosed with probable Creutzfeldt-Jakob disease. However, serum analysis showed a high titer of antithyroid antibodies. We started corticosteroid pulse therapy with subsequent aggravation of seizure activity including generalized myoclonus, epilepsia parialis continua, and ballistic dyskinesia, which was effectively treated with clonazepam.

Conclusion: We provide evidence of a case of Creutzfeldt-Jakob disease that exhibited clinical deterioration after corticosteroid therapy. Although histopathological confirmation with brain biopsy is not easily available in Creutzfeldt-Jakob disease patients, selective initiation of corticosteroid pulse therapy should be considered in cases of uncertain diagnosis for differentiation with Hashimoto's encephalopathy.

Keywords: Creutzfeldt-Jakob disease, Hashimoto's encephalopathy, Corticosteroid, Seizure

\section{Background}

Creutzfeldt-Jakob disease (CJD) is fatal prion disease characterized by rapidly progressive dementia, myoclonus, pyramidal and extrapyramidal signs, visual field defect, and cerebellar symptoms [1]. Hashimoto's encephalopathy is corticosteroid-responsive autoimmune encephalitis with

\footnotetext{
* Correspondence: neuroksy@snu.ac.kr

${ }^{2}$ Clinical Neuroscience Center, Seoul National University Bundang Hospital, 300 Gumi-dong, Bundang-gu, Seongnam-si, Gyeonggi-do 463-707, Republic of Korea

${ }^{3}$ Department of Neurology, Seoul National University College of Medicine, Seoul, Republic of Korea

Full list of author information is available at the end of the article
}

antithyroid antibodies that may have overlapping clinical symptoms with CJD, especially in the early phase of disease [2]. Hashimoto's encephalopathy is more common in female individuals, typically presenting in middle age with a fluctuating encephalopathy including rapid progressing dementia, seizure, psychiatric manifestations, myoclonus, ataxia, stroke-like episodes, and coma, although the clinical phenotype is variable [3]. Cerebrospinal fluid (CSF), electroencephalogram (EEG), and brain magnetic resonance imaging (MRI) findings are non-specific, and CJD diagnosis is based on an appropriate clinical phenotype with exclusion of other conditions, in addition to raised

\section{Ciomed Central}

(c) 2014 Jang et al. licensee BioMed Central Ltd. This is an Open Access article distributed under the terms of the Creative Commons Attribution License (http://creativecommons.org/licenses/by/4.0), which permits unrestricted use, distribution, and reproduction in any medium, provided the original work is properly credited. The Creative Commons Public Domain Dedication waiver (http://creativecommons.org/publicdomain/zero/1.0/) applies to the data made available in this article, unless otherwise stated. 
anti-thyroid antibodies (Tg-Ab and TPO-Ab). However, anti-thyroid antibodies are not specific to Hashimoto's encephalopathy and are common in healthy elderly people [4]. There is no obvious correlation between antibody levels and disease severity, and it is likely that the antibodies are not pathogenic but simply an epiphenomenon reflecting an underlying autoimmune inflammatory state [5]. Thus, it is widely considered that Hashimoto's encephalopathy should be relabeled as 'corticosteroid-responsive encephalopathy associated with autoimmune thyroiditis' [6], and that lack of such corticosteroid response should prompt review of diagnosis [4]. Among CJD mimics, Hashimoto's encephalopathy is particularly important as it is treatable with corticosteroids [7]. In our thorough review of the literature on CJD mimicking Hashimoto's encephalopathy or Hashimoto's encephalopathy mimicking CJD, we found no evidence of definite markers for differential diagnosis of CJD and Hashimoto's encephalopathy [2,8-14]. Here, we describe a case of a patient with definite CJD with high titers of anti-thyroid antibodies whose clinical symptom was aggravated as a dominant seizure after initiation of corticosteroid pulse therapy.

\section{Case presentation}

A 59-year-old woman was admitted because of blurred vision, dysarthria, myoclonic movement of bilateral upper and lower limbs, and rapidly progressive dementia. The symptoms had started approximately 1 month prior and progression was so rapid that she became akinetic and occasionally showed just a slight smile as a response to questioning over the last 2 weeks.

Her CSF was acellular with no evidence of bacterial or viral infection, but her 14-3-3 protein was positive. EEG showed periodic sharp waves $(1.5 \mathrm{~Hz})$ at the bilateral frontal or occipital areas with predominance in the left side. Contrast-enhanced MRI showed high signal intensities at the bilateral cerebral cortex, caudate nucleus, and putamen with left predominance (Figure 1). She was diagnosed with probable CJD according to the World Health Organization diagnostic criteria for sporadic CJD [15]. Sodium valproate (1200 mg/day) and clonazepam $(0.5 \mathrm{mg} /$ day $)$ were used for intermittent myoclonic jerk. Laboratory analysis showed high titers of anti-thyroid peroxidase antibody (TPO-Ab) (1370 IU/mL; normal value $<60 \mathrm{IU} / \mathrm{mL}$ ) and anti-thyroglobulin antibody (Tg-Ab) (167 IU/mL; normal value <60 IU/mL). However, the levels of thyroid-stimulating hormone (2.24 IU/ $\mathrm{mL}$; normal value $0.4-4.0 \mathrm{IU} / \mathrm{mL}$ ) and FT4 (1.23; normal value $0.89-1.79)$ were normal. Follow-up laboratory study shows persistent high titers of TPO-Ab, while the titer of $\mathrm{Tg}-\mathrm{Ab}$ was fluctuating around the normal upper limit. Thyroid sonography showed no gross abnormality.

Although she was diagnosed as probable CJD, corticosteroid pulse therapy with methylprednisolone $(1 \mathrm{~g}$ per day) was started on the $6^{\text {th }}$ day of admission for differential diagnosis with Hashimoto's encephalopathy, which is known to show excellent response to corticosteroid therapy. We observed alertness and myoclonic movement after careful initiation of corticosteroid therapy. Over the 2 days after starting corticosteroid treatment, she was in a akinetic mute state with no response to pain or visual response. We also observed two episodes of generalized clonic movement with eyeball deviation. We elevated the dose of sodium valproate, titrated to $1800 \mathrm{mg} /$ day, without subsequent improvement of myoclonic jerk. Her alertness kept worsening with aggravation of myoclonus, and she had a first generalized tonic-clonic seizure on the $4^{\text {th }}$ day of corticosteroid therapy. We added levetiracetam (1000 mg/day) and elevated the dose of sodium valproate (2400 mg/day). However, the frequency of seizures was increased and the EEG showed more periodic sharp waves in the bilateral hemispheres with background slowing compared with the previous EEG. Generalized myoclonic movement was observed almost continuously when she was awake. Thus, we elevated the dose and frequency of clonazepam, which effectively alleviated the myoclonic
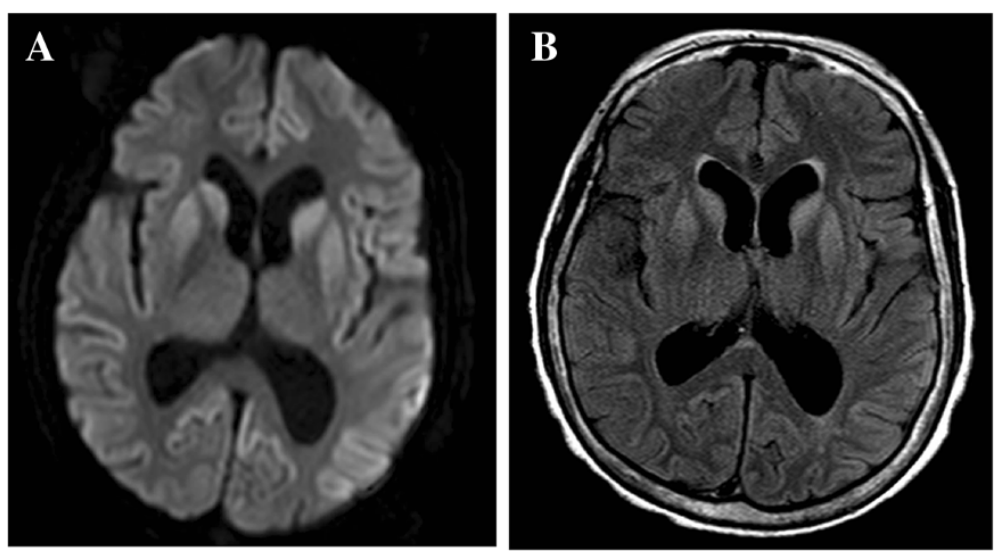

Figure 1 Patient MRI scans. Bilateral high signal intensities in the cortex, caudate nucleus, and putamen on DWI (A) and FLAIR (B). 
jerk, although she subsequently exhibited decreased mentality. As the five days of corticosteroid pulse therapy were suspected to aggravate the seizures, we performed a brain biopsy with family consent to confirm a diagnosis of CJD. Brain biopsy revealed neuronal loss, vacuolation and gliosis (Figure 2). Western blot demonstrated a protease-resistant pathogenic form of prion protein in the brain tissue. Genetic analysis demonstrated no known mutation in the PRNP gene. A diagnosis of definite CJD was made based on the above findings.

\section{Discussion}

CJD and Hashimoto's encephalopathy often share similar clinical features. However, there are no definite markers for differential diagnosis except for brain biopsy (Table 1). Clinical manifestation, EEG, brain imaging, and CSF findings including 14-3-3 protein can overlap between both disorders. The response to corticosteroid therapy is generally considered the only effective method for differential diagnosis before brain biopsy. Thus, in middle-aged female patients with a high titer of antithyroid antibodies, and who show dementia, myoclonus, ataxia, and altered consciousness, there is a mandatory recommendation to start corticosteroid therapy to rule out Hashimoto's encephalopathy [2]. Thus, we performed corticosteroid pulse therapy in our case.

What was unique in our patient is that her myoclonic seizure was distinctly aggravated as epilepsia partialis continua and secondary generalized tonic clonic seizure just after initiation of coritcosteroid pulse therapy. The semiology of her seizure was composed of mostly multifocal myoclonic movement, epilepsia partialis continua, and ballistic dyskinesia, which showed obvious improvement by clonazepam in addition to other anti-epileptic drugs. The response to clonazepam was so marked that an elevation of only $0.25 \mathrm{mg}$ decreased her mentality with subsequent improvement of myoclonic jerk.

To our knowledge, an aggravated seizure just after initiation of corticosteroid pulse therapy in definite CJD has not been previously reported. Although our case was in a course of deterioration, there was clear temporal correlation with the initiation of corticosteroid pulse and abrupt increase in seizure activity. From both acute and chronic models of epilepsy, there is evidence that high corticosteroid levels may exacerbate seizure occurrence $[16,17]$. Nevertheless, the symptomatology of our patient cannot be fully explained.

Focal motor or generalized seizures have been reported in $15-21 \%$ of patients with CJD during the later stage of the disease [18]. However, seizures as the presenting symptom of CJD are uncommon and occur in only approximately $3 \%$ of cases [19]. Based on five case reports in the literature, epilepsia partialis continua is reported as a presenting feature of CJD, although none of those cases were related to corticosteroid pulse therapy. The irritative, rather than destructive, nature of the cerebral damage may be the cause of the continuous jerks [20], while the loss of basal ganglia influence on the brain stem can also cause muscular twitches [21]. Our patient also showed ballistic movement, which was reduced by clonazepam treatment. Coexistence of generalized chorea and epilepsia partialis continua as the initial signs was previously reported in probable CJD, although the movement disorder typically appears during the later disease stage [22].

\section{Conclusion}

This is the first definite case of CJD with symptomatic aggravation after corticosteroid pulse therapy for differential

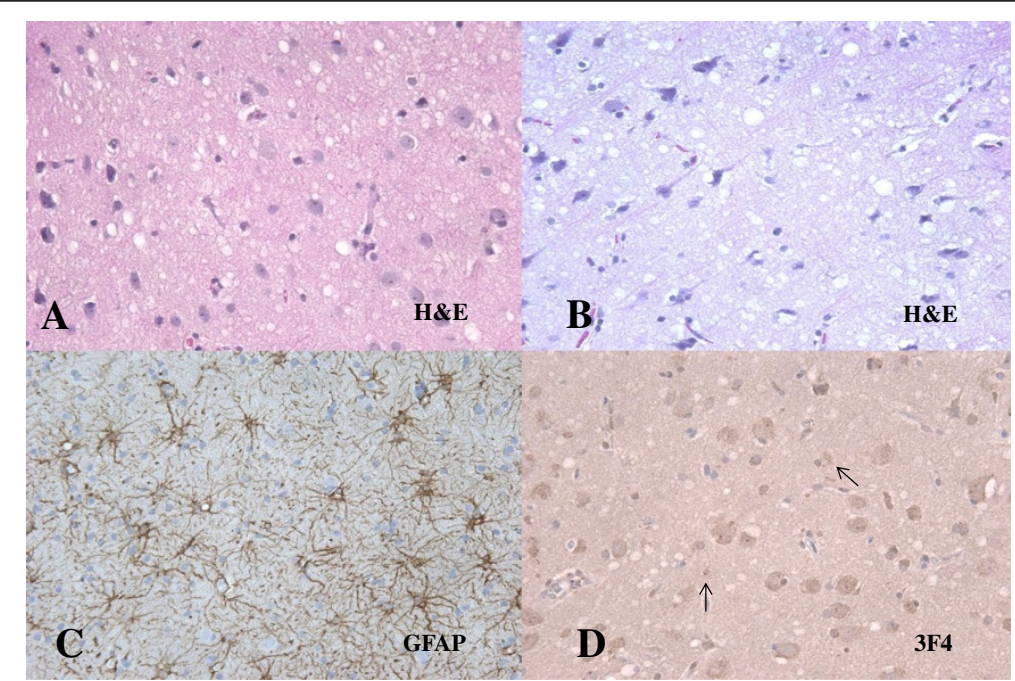

Figure 2 Brain biopsy finding of the patient. Spongiform changes with some neuronal cell loss and degeneration in H\&E (A, B). Increased gliosis in GFAP (C) and positive PrP ${ }^{5 C}$ in 3 F4 (D). 
Table 1 Previously reported cases with the feature of CJD and HE in need of differential diagnosis

\begin{tabular}{|c|c|c|c|c|c|c|c|c|c|}
\hline \multirow[t]{2}{*}{ Year/author } & \multirow[t]{2}{*}{$\begin{array}{l}\text { Final } \\
\text { diagnosis }\end{array}$} & \multirow[t]{2}{*}{ Clinical findings } & \multirow[t]{2}{*}{$\begin{array}{l}\text { Corticosteroid } \\
\text { response }\end{array}$} & \multirow[t]{2}{*}{ EEG finding } & \multirow[t]{2}{*}{ Brain image } & \multicolumn{2}{|c|}{ CJD work-up } & \multicolumn{2}{|c|}{$\begin{array}{l}\text { Hashimoto encephalopathy } \\
\text { work-up }\end{array}$} \\
\hline & & & & & & CSF study & Biopsy/gene & Lab & US/SCAN/FANA \\
\hline \multirow[t]{2}{*}{$\begin{array}{l}\text { 2004/Cho } \\
\text { et al. [14]. }\end{array}$} & \multirow[t]{2}{*}{ CJD } & $66 / F$ & - & \multirow[t]{2}{*}{$\begin{array}{l}\text { Bilateral frontal } \\
\text { SWC }(0.5-2 \mathrm{~Hz})\end{array}$} & $\begin{array}{l}\text { MRI (DWI): HSI at cortex, } \\
\text { caudate nucleus, putamen }\end{array}$ & \multirow[t]{2}{*}{ 14-3-3: + } & & TG-AB: WNL & $\begin{array}{l}\text { US: Chronic } \\
\text { thyroiditis }\end{array}$ \\
\hline & & $\begin{array}{l}\text { Dementia, parkinsonism, } \\
\text { visual symptom, ataxia, } \\
\text { myoclonus, akinetic mutism }\end{array}$ & & & $\begin{array}{l}\text { SPECT/PET: Rt. } \\
\text { Hemisphere: } \downarrow\end{array}$ & & & TPO-AB: $\uparrow$ & $\begin{array}{l}\text { FNA: PMN, } \\
\text { lymphocyte }\end{array}$ \\
\hline \multirow{4}{*}{$\begin{array}{l}\text { 2003/Cossu } \\
\text { et al. [2]. }\end{array}$} & \multirow[t]{4}{*}{ CJD } & $61 / F$ & \multirow[t]{4}{*}{-} & \multirow{4}{*}{$\begin{array}{l}\text { Periodic triphasic } \\
\text { wave }\end{array}$} & \multirow[t]{4}{*}{ MRI: normal } & \multirow[t]{4}{*}{ 14-3-3: + } & \multirow{4}{*}{$\begin{array}{l}\text { Biopsy: typical CJD } \\
\text { pattern, PRNP + } \\
\text { codon } 210,129\end{array}$} & TG-AB: $\uparrow$ & \\
\hline & & \multirow{3}{*}{$\begin{array}{l}\text { Visual symptom, ataxia, } \\
\text { myoclonus, mental } \\
\text { change }\end{array}$} & & & & & & TPO-AB: $\uparrow$ & \\
\hline & & & & & & & & $\mathrm{TSH}: \uparrow$ & \\
\hline & & & & & & & & T3, T4 : WNL & \\
\hline \multirow{3}{*}{$\begin{array}{l}\text { 2012/Kondziella } \\
\text { et al. [10]. }\end{array}$} & CJD & $67 / F$ & - & & & & & \multirow{3}{*}{$\begin{array}{l}\text { Anti-thyroid } \\
\text { antibody }(+)\end{array}$} & \\
\hline & $\mathrm{HE}$ & $63 / F$ & + & & & & & & \\
\hline & & $\begin{array}{l}\text { Dementia, ataxia, } \\
\text { myoclonus }\end{array}$ & & & & & & & \\
\hline \multirow[t]{4}{*}{$\begin{array}{l}\text { 2008/Cerqueira } \\
\text { et al. [8]. }\end{array}$} & \multirow[t]{4}{*}{$\mathrm{HE}$} & $68 / F$ & + & $\begin{array}{l}\text { Occasional sharp } \\
\text { waves }(2-3 \mathrm{~Hz})\end{array}$ & $\begin{array}{l}\text { MRI (T2WI): HSI at corona } \\
\text { radiata, centrum semiovale }\end{array}$ & & & T3, T4: WNL & \\
\hline & & \multirow{3}{*}{\multicolumn{2}{|c|}{$\begin{array}{l}\text { Cognitive decline, insomnia, } \\
\text { poor appetite, visual } \\
\text { hallucination, tremor, gait } \\
\text { disturbance, decreased } \\
\text { mentality, myoclonus }\end{array}$}} & & & & & TSH: $\uparrow$ & \\
\hline & & & & & & & & TPO-AB: $\uparrow$ & \\
\hline & & & & & & & & TG-AB: WNL & \\
\hline \multirow{2}{*}{$\begin{array}{l}\text { 2002/Doherty } \\
\text { et al. [9]. }\end{array}$} & \multirow[t]{2}{*}{$\mathrm{HE}$} & $57 / F$ & + & \multirow{2}{*}{$\begin{array}{l}\text { Bihemispheric } \\
\text { slowing, triphasic } \\
\text { wave }\end{array}$} & \multirow{2}{*}{$\begin{array}{l}\text { MRI (T2WI): HIS } \\
\text { at Lt. medial } \\
\text { frontal region }\end{array}$} & \multirow[t]{2}{*}{ 14-3-3: - } & \multirow{2}{*}{$\begin{array}{l}\text { Biopsy: spongiform } \\
\text { change }\end{array}$} & \multirow{2}{*}{ TPO-AB: $\uparrow$} & \multirow{7}{*}{$\begin{array}{l}\text { US: } \\
\text { hypoechoic area }\end{array}$} \\
\hline & & $\begin{array}{l}\text { Generalized seizure, } \\
\text { hallucination }\end{array}$ & & & & & & & \\
\hline 2004/Vander & $\mathrm{HE}$ & $58 / \mathrm{M}$ & + & Slow background, & MRI: normal & 14-3-3: + & & $\mathrm{TSH}: \uparrow$ & \\
\hline & & Confusion, myoclonus, & & $\begin{array}{l}\text { generalized delta } \\
\text { activity }\end{array}$ & & & & TG-AB: $\uparrow$ & \\
\hline & & $\begin{array}{l}\text { bilateral hyperreflexia, } \\
\text { babinski }(+) \text { generalized } \\
\text { seizure }\end{array}$ & & & & & & TPO-AB: $\uparrow$ & \\
\hline 2011/Santoro & $\mathrm{HE}$ & $66 / M$ & + & Slow theta and & MRI (DWI, T2WI): HSI & 14-3-3: -- & & TG-AB: $\uparrow$ & \\
\hline et al. [12]. & & $\begin{array}{l}\text { Confusion, GTC, fluctuating } \\
\text { alertness, myoclonic jerks }\end{array}$ & & delta waves & $\begin{array}{l}\text { at left white matter and } \\
\text { bilateral cortical region }\end{array}$ & & & & \\
\hline
\end{tabular}


Table 1 Previously reported cases with the feature of CJD and HE in need of differential diagnosis (Continued)

\begin{tabular}{|c|c|c|c|c|c|c|c|}
\hline \multirow{5}{*}{$\begin{array}{l}\text { 2004/Sakuria } \\
\text { et al. [11]. }\end{array}$} & \multirow[t]{5}{*}{$\mathrm{HE}$} & \multirow[t]{2}{*}{$79 / F$} & \multirow[t]{5}{*}{+} & \multirow{5}{*}{$\begin{array}{l}\text { Diffuse slowing, } \\
\text { periodic synchronous } \\
\text { discharge }\end{array}$} & \multirow{5}{*}{$\begin{array}{l}\text { MRI (T2WI): HSI at } \\
\text { periventricular and } \\
\text { basal ganglia lesion }\end{array}$} & \multirow[t]{5}{*}{ 14-3-3: + } & TG-AB: $\uparrow$ \\
\hline & & & & & & & TPO-AB: $\uparrow$ \\
\hline & & \multirow[t]{3}{*}{$\begin{array}{l}\text { Dementia, gait, } \\
\text { inactivity, myoclonus }\end{array}$} & & & & & $\begin{array}{l}\text { TSH-receptor } \\
\mathrm{AB}: \uparrow\end{array}$ \\
\hline & & & & & & & TPO-AB: $\uparrow$ \\
\hline & & & & & & & $\begin{array}{l}\text { TSH-receptor } \\
\mathrm{AB}: \uparrow\end{array}$ \\
\hline
\end{tabular}

CJD Creutzfeldt-Jakob disease; HE Hashimoto's encephalopathy; GTC generalized tonic-clonic seizure; DWI diffusion-weighted images; HSI high signal intensity; Tg-Ab anti-thyroglobulin antibody; TPO-Ab anti-thyroid peroxidase antibody; US ultrasonography; FNA fine needle aspiration; PMN polymorphonuclear leukocytes. 
diagnosis with Hashimoto's encephalopathy. In our patient, the high titer of anti-thyroid antibodies may have been an incidental finding, as the thyroid sonography was normal and brain biopsy confirmed final diagnosis as sporadic CJD that was abruptly aggravated by corticosteroids. When a middle-aged woman diagnosed with probable CJD shows a high titer of anti-thyroid antibodies, corticosteroid treatment is typically used as histopathological confirmation with brain biopsy is not easily available, with expectations of near complete recovery in cases of Hashimoto's encephalopathy. However, if corticosteroid pulse therapy can cause rapid deterioration or seizure aggravation of CJD, the use of corticosteroids in probable CJD patients with high titers of anti-thyroid antibodies should be cautioned. Our patient showed very typical clinical symptoms, and EEG, MRI and CSF findings (14-3-3 protein) of CJD. Thus, it may be reasonable to selectively start corticosteroid pulse therapy in cases of uncertain diagnosis. If seizures are aggravated by corticosteroid treatment, clonazepam may be a good choice to reduce myoclonic jerk, in addition to anti-epileptic drugs. Further studies are required to prove a correlation between corticosteroid treatment and symptomatic aggravation of CJD.

\section{Consent}

Written informed consent was obtained from the caregiver of our patient for publication of this Case report and any accompanying images. A copy of the written consent is available for review by the Editor of this journal.

\section{Competing interests}

The authors declare that they have no competing interests.

\section{Authors' contributions}

JWJ was involved in study concept and design, collection of data, and drafting, reviewing, and critiquing the manuscript. SYK was involved in study concept and design, collection of data, drafting, reviewing, and critiquing the manuscript, and supervision. SYP, YHP, and JEK revised and critiqued the manuscript. All authors read and approved the final manuscript.

\section{Acknowledgment}

We thank the family of the patient presented here, whose help made this work possible.

\section{Author details}

'Department of Neurology, Kangwon National University Hospital, Chuncheon, Republic of Korea. ${ }^{2}$ Clinical Neuroscience Center, Seoul National University Bundang Hospital, 300 Gumi-dong, Bundang-gu, Seongnam-si, Gyeonggi-do 463-707, Republic of Korea. ${ }^{3}$ Department of Neurology, Seoul National University College of Medicine, Seoul, Republic of Korea.

Received: 21 August 2013 Accepted: 3 September 2014 Published: 8 September 2014

\section{References}

1. Brown P, Gibbs CJ Jr, Rodgers-Johnson P, Asher DM, Sulima MP, Bacote A, Goldfarb LG, Gajdusek DC: Human spongiform encephalopathy: the National Institutes of Health series of 300 cases of experimentally transmitted disease. Ann Neurol 1994, 35(5):513-529.

2. Cossu G, Melis M, Molari A, Pinna L, Ferrigno P, Melis G, Zonza F, Spissu A: Creutzfeldt-Jakob disease associated with high titer of antithyroid autoantibodies: case report and literature review. Neurol Sci 2003, 24(3):138-140.

3. Schiess N, Pardo CA: Hashimoto's encephalopathy. Ann N Y Acad Sci 2008 1142:254-265

4. Murray K: Creutzfeldt-Jacob disease mimics, or how to sort out the subacute encephalopathy patient. Pract Neurol 2011, 11(1):19-28.

5. Mocellin R, Walterfang M, Velakoulis D: Hashimoto's encephalopathy: epidemiology, pathogenesis and management. CNS Drugs 2007, 21(10):799-811.

6. Castillo P, Woodruff B, Caselli R, Vernino S, Lucchinetti C, Swanson J, Noseworthy J, Aksamit A, Carter J, Sirven J, Hunder D, Fatourechi V, Mokri B, Drubach D, Pittock S, Lennon V, Boeve B: Steroid-responsive encephalopathy associated with autoimmune thyroiditis. Arch Neurol 2006, 63(2):197-202.

7. Chong JY, Rowland LP, Utiger RD: Hashimoto encephalopathy: syndrome or myth? Arch Neurol 2003, 60(2):164-171.

8. de Cerqueira AC, Bezerra JM, de Magalhaes GC, Rozenthal M, Nardi AE: Hashimoto's encephalopathy with clinical features similar to those of Creutzfeldt-Jakob disease. Arq Neuropsiquiatr 2008, 66(4):903-905.

9. Doherty CP, Schlossmacher M, Torres N, Bromfield E, Samuels MA, Folkerth R Hashimoto's encephalopathy mimicking Creutzfeldt-Jakob disease: brain biopsy findings. J Neurol Neurosurg Psychiatry 2002, 73(5):601-602.

10. Kondziella D, Hansen K, Gonzalez T, Gideon P, Christiansen I, Sellebjerg F: Anti-thyroid antibodies in two patients with subacute dementia, ataxia, and myoclonus. Ugeskr Laeger 2012, 174(9):577-579.

11. Sakurai T, Tanaka Y, Koumura A, Hayashi Y, Kimura A, Hozumi I, Yoneda M, Inuzuka T: Case report of a patient with Hashimoto's encephalopathy associated with Basedow's disease mimicking Creutzfeldt-Jakob disease. Brain Nerve 2008, 60(5):559-565.

12. Santoro D, Colombo I, Ghione I, Peverelli L, Bresolin N, Sciacco M, Prelle A: Steroid-responsive Hashimoto encephalopathy mimicking CreutzfeldtJakob disease. Neurol Sci 2011, 32(4):719-722.

13. Vander T, Hallevy C, Alsaed I, Valdman S, Ifergane G, Wirguin I: 14-3-3 protein in the CSF of a patient with Hashimoto's encephalopathy. J Neurol 2004, 251(10):1273-1274.

14. Cho Y-J, Park CH, Paik JW, Shin H-W, Park C-W, Park S, Kim HO, Kim Y-S: A case of probable Ceutzfeldt-Jakob disease with coexistence of the feature of Hashimoto encephalopathy. J Korean Neurol Assoc 2004, 22(4):406-409.

15. Zerr I, Kallenberg K, Summers DM, Romero C, Taratuto A, Heinemann U, Breithaupt M, Varges D, Meissner B, Ladogana A, Schuur M, Haik S, Collins SJ, Jansen GH, Stokin GB, Pimentel J, Hewer E, Collie D, Smith P, Roberts H, Brandel JP, van Duijn C, Pocchiari M, Begue C, Cras P, Will RG, Sanchez-Juan P: Updated clinical diagnostic criteria for sporadic Creutzfeldt-Jakob disease. Brain 2009, 132(Pt 10):2659-2668.

16. Roberts AJ, Keith LD: Corticosteroids enhance convulsion susceptibility via central mineralocorticoid receptors. Psychoneuroendocrinology 1995 20(8):891-902

17. Kling MA, Smith MA, Glowa JR, Pluznik D, Demas J, DeBellis MD, Gold PW, Schulkin J: Facilitation of cocaine kindling by glucocorticoids in rats. Brain Res 1993, 629(1):163-166.

18. Cokgor I, Rozear M, Morgenlander JC: Seizures and Creutzfeldt-Jakob disease. A case report and series review. N C Med J 1999, 60(2):108-109.

19. Aronyk K, Petito F, Solomon GE: Partial elementary motor seizures as the first symptom of Creutzfeldt-Jakob disease. Ann Neurol 1984, 15(2):210-211.

20. Taskiran A, Tezer Fl, Saygi S: Epilepsia partialis continua as the presenting symptom in probable sporadic Creutzfeldt-Jakob disease. Epileptic Disord 2011, 13(1):82-87.

21. Cockerell OC, Rothwell J, Thompson PD, Marsden CD, Shorvon SD: Clinical and physiological features of epilepsia partialis continua. Cases ascertained in the UK. Brain 1996, 119(Pt 2):393-407.

22. Donmez B, Cakmur R, Men S, Oztura I, Kitis A: Coexistence of movement disorders and epilepsia partialis continua as the initial signs in probable Creutzfeldt-Jakob disease. Mov Disord 2005, 20(9):1220-1223.

doi:10.1186/s12883-014-0179-y

Cite this article as: Jang et al:: Symptomatic aggravation after corticosteroid pulse therapy in definite sporadic Creutzfeldt-Jakob disease with the feature of Hashimoto's encephalopathy. BMC Neurology 2014 14:179. 